\title{
TINGKAT KESUBURAN DAN POTENSI PRODUKSI UDANG VANAME DI TAMBAK UPT PERIKANAN AIR PAYAU DAN LAUT PROBOLINGGO
}

\author{
Setya Widi Ayuning Permanasari\#, Samuel Saputra, Kusriani, dan Putut Widjanarko \\ Fakultas Perikanan dan IImu Kelautan, Universitas Brawijaya \\ Jl. Veteran, Malang 65149, Jawa Timur
}

(Naskah diterima: 13 Desember 2018; Revisi final: 1 April 2019; Disetujui publikasi: 1 April 2019)

\begin{abstract}
ABSTRAK
Keberlanjutan kegiatan pertambakan sangat tergantung pada kondisi kualitas lingkungan perairan dalam mendukung potensi produksi biota budidaya. Namun, dalam pengelolaan juga perlu diketahui potensi lingkungan dalam memproduksi biota. Penelitian ini bertujuan untuk mengukur tingkat kesuburan perairan pada tambak serta mengestimasi produksi udang yang dihasilkan dengan pendekatan Produktivitas Primer. Penelitian dilakukan di tambak UPT Probolinggo, Fakultas Perikanan dan Ilmu Keluatan, Universitas Brawijaya. Analisis kesuburan perairan tambak dilakukan menggunakan metode Tropic State Index (TSI), dan pendugaan produksi udang dengan pendekatan metode Beveridge dengan mengkonversi nilai Produktivitas Primer, dimana nilai Produktivitas Primer dapat dihitung dengan mentransformasi nilai Klorofil-a. Rata-rata hasil pengukuran klorofil-a pada tambak 1 sebesar 23,06 mg/m³ dan pada tambak 2 sebesar 20,62 mg/m³. Tingkat kesuburan pada kedua tambak menunjukkan perairan eutrofik sedang. Rata-rata potensi produksi udang pada tambak 1 adalah 13,22 ton C-udang/2700m²/tahun; dan tambak 2 adalah 10,90 ton C-udang/ $2700 \mathrm{~m}^{2} /$ tahun. Korelasi antara nilai klorofil-a dan estimasi produksi udang menunjukkan nilai korelasi < 0,199 yang artinya keeratan kedua variabel sangat rendah. Namun korelasi antara klorofil-a dan PP memiliki hubungan yang sangat kuat yaitu $>0,99$.
\end{abstract}

KATA KUNCl: kualitas air; produktivitas perairan; potensi perikanan; status trofik

ABSTRACT: Eutrophic level and productivity of Vaname shrimp ponds of the Technical Extension Office for Brackish and Marine Fisheries Probolinggo. By: Setya Widi Ayuning Permanasari, Samuel Saputra, Kusriani, and Putut Widjanarko

\begin{abstract}
The sustainability of aquacultureactivities highly depends on the water quality conditions of theaquatic environment. Thus, determining the existing environmental condition of fish culture followed by regular monitoring is necessary to ensure the optimum production of farmed fish. The purpose of this current research was to determinethe eutrophication level in shrimp ponds and estimate its shrimp production using the approach of Primary Productivity. The study was conducted in the shrimp ponds managed by the Probolinggo Technical Extension Office, Faculty of Fisheries and Marine Science, Brawijaya University. The eutrophication level was determined used the Tropic State Index (TSI) method. Shrimp production was estimated using the Beveridge M ethod by which the primary productivity values were calculated by transforming the Chlorophyll-a values. The results showed that the average contents of chlorophyll-a in pond 1 and pond 2 were $23.06 \mathrm{mg} \cdot \mathrm{m}^{-3}$ and $20.62 \mathrm{mg} \cdot \mathrm{m}^{-3}$, respectively. The eutrophication levels in both ponds indicate moderate eutrophic water. The estimated shrimp productions in ponds 1 and 2 were 13.22 and 10.90 tons Cshrimp $2700 \mathrm{~m}^{-2}$ year-1 ${ }^{-1}$ respectively. The correlation value between the chlorophyll-a levels and estimated shrimp productions was $<0.199$ which means that the relationship between the two variables is unsubtantial. On the other hand, the chlorophyll-a and primary productivity had a very strong relationship indicated by the correlation value of $>$ 0.99 .
\end{abstract}

KEYWORDS: aquatic productivity; fisheries potential; trophic status; water quality

\footnotetext{
* Korespondensi: Fakultas Perikanan dan IImu Kelautan,

Universitas Brawijaya. Jl. Veteran, Malang 65145, Jawa Timur,

Indonesia

Tel.: + 62341553512

E-mail: setya_widhi3@ub.ac.id; widipangestu@ub.ac.id
} 


\section{PENDAHULUAN}

Tambak merupakan suatu bangunan di daerah pesisir pantai yang berbentuk seperti kolam, yang dimanfaatkan oleh masyarakat sebagai tempat pemeliharaan dan pembesaran biota yang bernilai ekonomis (Raswin, 2003). Kondisi lingkungan di daerah pertambakan dipengaruhi oleh adanya masukan antara air tawar dan air laut yang bersatu membentuk suatu ekologi yang khas, sehingga mengakibatkan lingkungan pertambakan mudah berubah-ubah salah satunya adalah kesuburan perairan. Kesuburan perairan menggambarkan kondisi perairan dalam menyediakan unsur hara yang sesuai bagi kehidupan alga sehingga menghasilkan produksi yang optimum. Perairan yang subur mengandung unsur hara yang dapat mempercepat pertumbuhan dan biomassa (Purwohadiyanto et al., 2006).

Kesuburan perairan dapat memengaruhi produktivitas pada kegiatan budidaya. Akhir-akhir ini produktivitas pada tambak udang mengalami penurunan. Terjadinya penurunan produktivitas tambak dikarenakan semakin lama umur tambak beroperasi maka akan memengaruhi faktor kualitas lingkungannya (Nirmala et al., 2005). Perubahan kondisi kualitas air yang berubah dapat berpengaruh terhadap daya dukung lingkungan untuk menopang kehidupan organisme yang tinggal di lingkungan tersebut. Salah satunya yaitu kemampuan lingkungan dalam memproduksi produktivitas primer, yang selanjutnya akan memengaruhi produksi udang. Walaupun sistem yang digunakan oleh kegiatan budidaya sudah menuju teknologi yang paling canggih, semisal sistem intensif, super intensif, dan supra intensif.

Daya dukung lingkungan atau carrying capacity merupakan suatu refleksi atau gambaran dari kapasitas penyangga lingkungan. Penentuan carrying capacity ini bertujuan untuk mengetahui kemampuan ekosistem dalam mendukung semua proses kehidupan organisme untuk mempertahankan produktivitasnya maupun metabolisme sel dalam tubuhnya (Beveridge, 1984). Selain itu, daya dukung suatu lingkungan juga dapat menjabarkan mengenai potensi produksi dari usaha budidaya, sehingga dalam pengelolaan sumber daya perikanan tambak dapat berkelanjutan dan tidak menimbulkan limbah yang berefek pada kerusakan lingkungan sekitarnya. Oleh karena itu, perlu adanya informasi mengenai kondisi kualitas air yang mendukung produktivtas primer, sehingga dapat mengestimasi potensi udang yang dapat diproduksi dari kondisi perairan tersebut.

\section{BAHAN DAN METODE}

\section{Sampling}

Sampel air diambil dari tambak UPT Fakultas Perikanan dan IImu Kelautan, Universitas Brawijaya, menggunakan dua petak tambak dengan luas 2.700 meter persegi, dengan sistem insentif. Terdapat 11 petak tambak dengan komoditas udang vaname (dua petak intensif dan dua petak semi-intensif) dan sisanya digunakan untuk memelihara ikan bandeng. Pengambilan sampel air dilakukan pada pertengahan bulan Agustus sampai Oktober (dua minggu sekali), di mana terdapat dua petak intensif udang vaname. Analisis kualitas air dilakukan di UPT BPAP Bangil, Pasuruan, kecuali untuk Klorofil-a dilakukan di Laboratorium IImu-IImu Perairan, Fakultas Perikanan dan IImu Kelautan, Universitas Brawijaya.

Pengambilan sampel air dilakukan di tiga titik pertambakan yaitu inlet, outlet, dan tengah tambak setiap pukul 10.00 WIB. Lokasi tambak terletak pada

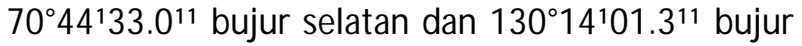
timur. Sampel air yang diambil secepatnya dimasukkan ke dalam coolbox dan diawetkan dengan menggunakan es batu untuk segera dibawa ke laboratorium.

Analisis kualitas air yang diukur secara insitu adalah suhu dan oksigen terlarut (OT) dengan alat DO meter YSI, kecerahan dengan secchi disk, $\mathrm{pH}$ dengan $\mathrm{pH}$ meter Eutech, sedangkan parameter lainnya dilakukan di Laboratorium Kualitas Air UPT. BPAP Bangil Pasuruan seperti karbondioksida $\left(\mathrm{CO}_{2}\right)$ dengan titrasi, ortofosfat, dan nitrat dengan kit, total organic matter (TOM) dengan titrasi. Spektrofotometer yang digunakan oleh UPT BPAP Bangil adalah Colorimeter dr 890, dan klorofil-a dengan menggunakan spektrofotometer merk.

\section{Pengukuran Klorofil-a}

Pengukuran konsentrasi klorofil-a dilakukan dengan menggunakan metode spektrofotometer. Konsentrasi klorofil-a dihitung dengan menggunakan rumus Vollenweider (1969) dalam Permanasari et al. (2017), sebagai berikut:

$$
\mathrm{Chl}-\mathrm{a}\left(\frac{\mathrm{mg}}{\mathrm{m}^{3}}\right)=11,9(\mathrm{~A} 665-\mathrm{A} 750) \times \frac{\mathrm{V}}{\mathrm{L}} \times \frac{1000}{\mathrm{~s}}
$$

$$
\begin{array}{ll}
\text { di mana: } & \\
11,9 & =\text { konstanta } \\
\mathrm{A} 665 & =\text { absorbansi spektrofotometer } 665 \mathrm{~nm} \\
\mathrm{~A} 750 & =\text { absorbansi spektrofotometer } 750 \mathrm{~nm} \\
\mathrm{~V} & =\text { volume ekstrak aceton }(\mathrm{mL}) \\
\mathrm{L} & =\text { lebar diameter cuvet }(1 \mathrm{~cm}) \\
\mathrm{S} & =\text { volume sampel air yang di saring }(\mathrm{L})
\end{array}
$$


Tabel 1. Kategori status trofik berdasarkan pada trophic state index Carlson (1977)

Table 1. The trophic status category is based on trophic state index Carlson (1977)

\begin{tabular}{cc}
\hline Skor TSI & Status trofik perairan \\
\hline$<30$ & Ultraoligotrofik \\
$30-40$ & Oligotrofik \\
$40-50$ & Mesotrofik \\
$50-60$ & Eutrofik ringan \\
$60-70$ & Eutrofik sedang \\
$70-80$ & Eutrofik berat \\
$>80$ & Hipereutrofik yang disertai blooming algae \\
\hline
\end{tabular}

Sumber (Source): Carlson (1977) dalam Permanasari et al. (2017)

\section{Analisis Data}

\section{Perhitungan Tropic State Index (TSI)}

Dalam menentukan status trofik dapat digunakan berbagai metode, namun dalam penelitian ini menggunakan metode TSI (tropic state index) yang telah dikembangkan oleh Carlson (1977), dengan perhitungan sebagai berikut:

$$
\begin{aligned}
& \text { TSI }(\mathrm{SD})=10\left(6-\frac{\ln \mathrm{SD}}{\ln 2}\right) \\
& \mathrm{TSI}(\mathrm{Chl})=10\left(6-\frac{2.04-0.68 \ln \mathrm{Chl}}{\ln 2}\right) \\
& \mathrm{TSI}(\mathrm{TP})=10\left(6-\frac{\ln \frac{48}{\mathrm{TP}}}{\ln 2}\right) \\
& \text { Rataan TSI }=\left(\frac{\mathrm{TSI}(\mathrm{SD})+\mathrm{TSI}(\mathrm{Chl})+\mathrm{TSI}(\mathrm{TP})}{3}\right)
\end{aligned}
$$

di mana:

$\mathrm{TSI}=$ tropic state index

$\mathrm{SD}=$ kecerahan perairan (secchi disk)

$\mathrm{Chl}=$ klorofil-a

$\mathrm{TP}=$ ortofosfat

Setelah mendapatkan rataan TSI maka penentuan status trofik perairan dapat dikategorikam berdasarkan pada nilai TSI (Tabel 1).

\section{Produktivitas Primer}

Produktivitas primer diukur dengan mentransformasi nilai dari klorofil-a, yang dimasukkan ke dalam rumus Beveridge (1984):

$$
\begin{aligned}
& \text { Bobot basah udang }\left(\mathrm{g} \mathrm{C}-\mathrm{ikan} / \mathrm{m}^{2} / \text { tahun }\right)= \\
& \text { Nilai \%konversi X PP }
\end{aligned}
$$

\section{Pendugaan Potensi Udang dengan Pendekatan Produktivitas Primer}

Estimasi potensi produksi perikanan (dalam hal ini udang) dihitung menggunakan nilai produktivitas primer (PP), dengan cara mengonversikan nilai produktivitas primer menjadi bobot basah yang dihasilkan setiap tahun pada luasan area tertentu. Proses konversi ini dilakukan dengan mengubah nilai $\mathrm{PP}$ (g C/m²/tahun) menjadi g C-ikan $/ \mathrm{m}^{2} /$ tahun, mengacu pada pendapat (Beveridge, 1984):

$$
\mathrm{PP}=56.5 \times(\text { Klorofil }-\mathrm{a})^{0.61}
$$

\section{Penentuan Persentase Konversi}

Penentuan persentase konversi dilakukan menggunakan rumus interpolasi, di mana nilai persentase konversi produksi ikan berdasarkan Beveridge (1984):

$$
Y=Y_{1}+\left(\frac{X-X_{1}}{X_{2}-X_{1}}\right) \times\left(Y_{2}-Y_{1}\right)
$$

$$
\begin{array}{ll}
\text { di mana: } & \\
Y^{\prime}= & \text { nilai konversi (\% } \\
X & =\text { nilai PP dalam setahun }\left(\mathrm{g} \mathrm{C} / \mathrm{m}^{2} / \text { tahun }\right) \\
Y_{1}= & \text { persentase konversi awal dapat dilihat pada tabel } \\
Y_{2}= & \text { Beveridge } \\
X_{1}= & \text { Beventase konversi akhir dapat dilihat pada tabel } \\
X_{2}= & \text { Jumlah }(\Sigma) \text { PP awal } \\
\end{array}
$$

\section{Estimasi Potensi Perikanan}

Potensi perikanan dalam suatu ekosistem dapat diduga dengan menggunakan rumus Beveridge (1984), sebagai berikut:

$$
\begin{aligned}
& \text { Potensi ikan }(\mathrm{g} C-i \text { ikan/tahun })= \\
& \text { Bobot basah ikan x luas perairan }
\end{aligned}
$$




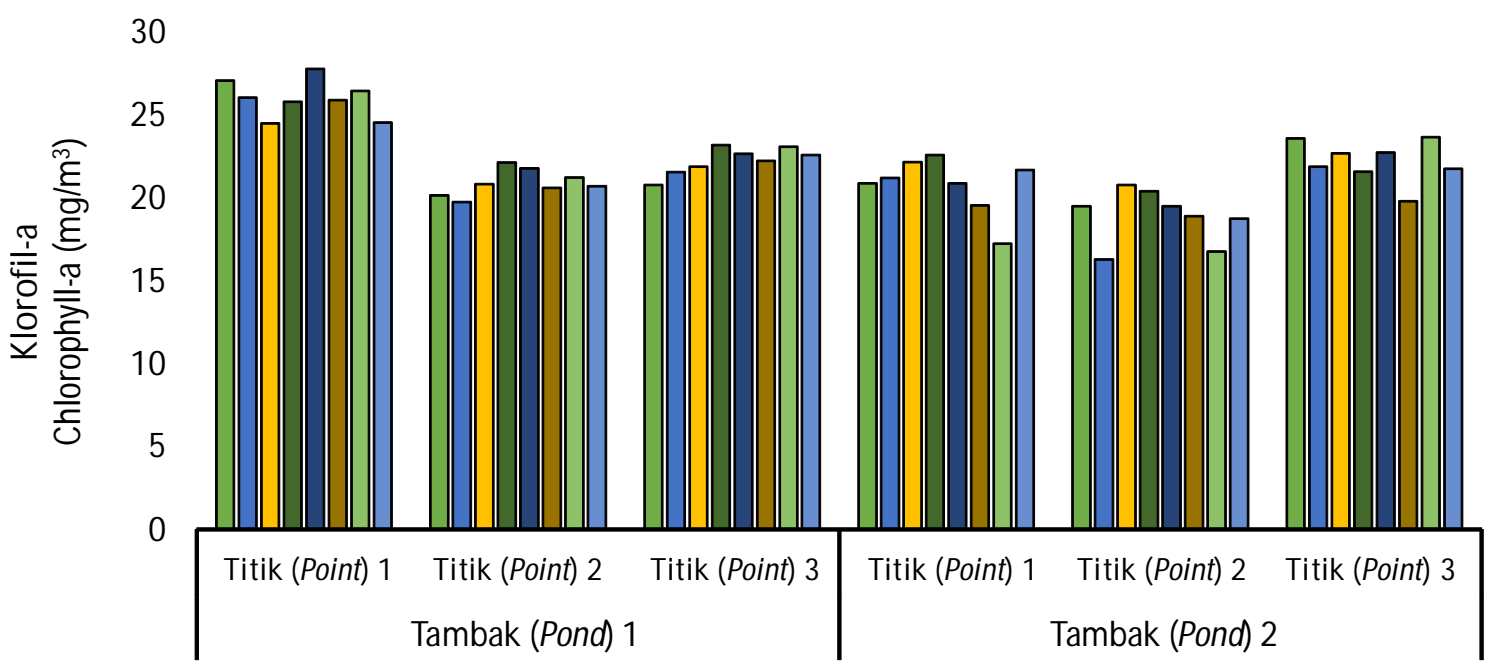

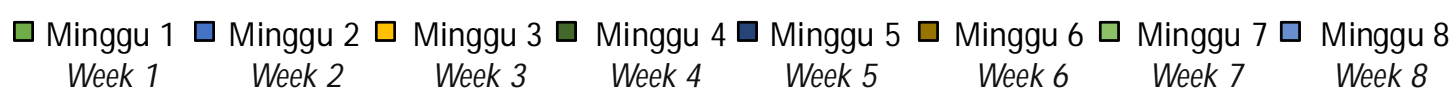

Gambar 1. Kandungan klorofil-a $\left(\mathrm{mg} / \mathrm{m}^{3}\right)$ pada tambak UPT Perikanan Air Payau dan Laut, Probolinggo.

Figure 1. Content of chlorophyll-a $\left(\mathrm{mg} / \mathrm{m}^{3}\right)$ in ponds of UPT Brackish and Sea Water Fisheries, Probolinggo.

\section{HASIL DAN BAHASAN}

Hasil analisis kualitas air menunjukkan semua parameter berkisar pada kondisi optimum bagi kehidupan udang (Tabel 4). Distribusi secara temporal untuk semua parameter uji berfluktuatif, hal ini dikarenakan sesuai dengan kondisi lingkungan pada saat pengambilan sampel. Dalam usaha budidaya udang klorofil-a merupakan faktor penting, hal ini dianggap bahwa klorofil-a bertugas sebagai mediator pada proses fotosintesis dan bertanggung jawab dalam menentukan produktivitas primer. Semakin tinggi kandungan klorofil-a dalam perairan, maka akan semakin tinggi pula tingkat kesuburan perairan. Klorofil-a merupakan parameter yang dapat digunakan untuk menduga kelimpahan fitoplankton dan

Tabel 2. Rataan nilai TSI pada tambak udang vaname pada setiap minggunya Table 2. Average TSI value in white shrimp ponds every week

\begin{tabular}{|c|c|c|c|c|c|c|}
\hline \multirow{3}{*}{$\begin{array}{l}\text { Waktu (minggu) } \\
\text { Time (weeks) }\end{array}$} & \multicolumn{6}{|c|}{ Rataan TSI (Average TSI) } \\
\hline & \multicolumn{3}{|c|}{ Tambak-1 (Pond-1) } & \multicolumn{3}{|c|}{ Tambak-2 (Pond-2) } \\
\hline & ST-1 & ST-2 & ST-3 & ST-1 & ST-2 & ST-3 \\
\hline 1 & 67.40 & 66.04 & 69.07 & 64.40 & 64.40 & 65.78 \\
\hline 2 & 66.60 & 65.90 & 68.40 & 62.38 & 60.38 & 65.48 \\
\hline 3 & 70.93 & 65.59 & 70.25 & 66.53 & 62.88 & 66.96 \\
\hline 4 & 68.60 & 64.97 & 69.38 & 63.72 & 64.39 & 66.15 \\
\hline 5 & 68.03 & 63.93 & 68.85 & 64.93 & 62.89 & 66.36 \\
\hline 6 & 66.03 & 66.11 & 67.44 & 64.21 & 60.98 & 64.60 \\
\hline 7 & 64.49 & 66.08 & 69.07 & 64.33 & 63.91 & 64.17 \\
\hline 8 & 68.41 & 65.53 & 69.23 & 64.43 & 65.57 & 65.01 \\
\hline Rataan (Average) & 67.56 & 65.52 & 68.96 & 64.37 & 63.18 & 65.56 \\
\hline Rataan TSI (Average TSI ) & & 67.35 & & & 64.37 & \\
\hline $\begin{array}{l}\text { Standar deviasi } \\
\text { Standard deviation }\end{array}$ & 1.93 & 0.75 & 0.81 & 1.16 & 1.78 & 0.94 \\
\hline
\end{tabular}


produktivitas primer. Distribusi temporal Klorofil-a tersaji pada Gambar 1.

Selama penelitian pada kedua petak tambak kisaran kandungan klorofil-a yaitu $16,78-27,1 \mathrm{mg} / \mathrm{m}^{3}$. Perairan tersebut tergolong pada perairan mesotrofik. Perairan dengan kandungan klorofil 8-25 mg/m³ tergolong dalam perairan mesotrofik (Ryding \& Rast, 1989). Hasil perhitungan trophic stateindex (TSI) untuk menentukan status trofik suatu perairan didapatkan nilai rataan TSI dari perhitungan TSI klorofil-a, TSI Secchi-disk, TSI ortofosfat tersaji dalam Tabel 2.

Penentuan status trofik perairan dengan metode TSI didapatkan nilai rataan TSI pada petak-1 adalah 67,13 dan 64,37 untuk petak-2. Berdasarkan hasil perhitungan ini, maka perairan tambak dapat digolongkan dalam kategori eutrofik sedang. Menurut Carlson (1977) dalam Permanasari et al. (2017), menyatakan bahwa perairan dengan nilai rataan TSI sebesar 60-70, tergolong dalam perairan eutrofik sedang. Dalam usaha tambak kondisi perairan tersebut masih tergolong baik, untuk menyediakan pakan alami bagi udang.

Hasil pengukuran produktivitas dengan metode klorofil-a selama penelitian berkisar 5,35-5,60 g C/ $\mathrm{m}^{3} /$ hari. Produktivitas primer memiliki hubungan erat dengan keberadaan fitoplakton, apabila nilai produktivitas primer dalam perairan tinggi maka kelimpahan fitoplankton akan tinggi pula (Permanasari et al., 2017). Produktivitas primer dalam penelitian ini dapat dikatakan baik, sehingga kemampuan perairan dalam mendukung kehidupan biota budidaya berjalan dengan baik. Potensi perikanan udang vaname yang dapat diproduksi dengan pendekatan nilai PP, tersaji pada Tabel 3.

Berdasarkan hasil perhitungan konversi produktivitas primer menjadi bobot basah udang, maka dapat diestimasi produksi udang pada tambak UPT Perikanan Air Payau dan Laut, Probolinggo berkisar 4,41 ton C-udang/panen pada petak-1 dan 3,63 ton C-udang/panen. Menurut informasi dari Kepala UPT Air Payau dan Laut, Probolinggo; Dr. Ir. Muhammad Musa, M.S., yang disampaikan pada saat rapat di tingkat Fakultas mengatakan bahwa hasil sekali panen yang didapatkan pada tahun 2018 adalah sebesar 3,5 ton dengan ukuran 60 ekor/kg untuk tambak intensif udang vaname yang pada saat itu hanya terdapat dua petak.

Kisaran suhu selama penelitian pada kedua tambak masih tergolong baik untuk kehidupan udang, yaitu $27^{\circ} \mathrm{C}-29^{\circ} \mathrm{C}$. Suhu perairan yang baik untuk pertumbuhan udang berkisar $26^{\circ} \mathrm{C}-30^{\circ} \mathrm{C}$, hal ini dikarenakan pada kisaran tersebut udang mampu mencerna makanan dengan baik yang disertai dengan peningkatan pertumbuhan (Amri \& Kanna, 2008). Tingkat kecerahan perairan selama penelitian berkisar 26-50 cm. Tingkat kecerahan ini berpengaruh pada

Tabel 3. Potensi perikanan udang vaname di tambak UPT Perikanan Air Payau dan Laut, Probolinggo Table 3. The potential of vannamei shrimp fisheries in ponds UPT Brackish and Sea Water Fisheries, Probolinggo

\begin{tabular}{|c|c|c|c|c|}
\hline \multirow[b]{2}{*}{$\begin{array}{l}\text { Waktu (minggu) } \\
\text { Time (weeks) }\end{array}$} & \multicolumn{2}{|c|}{ Tambak-1 (Pond-1) } & \multicolumn{2}{|c|}{ Tambak-2 (Pond-2) } \\
\hline & $\begin{array}{l}\text { Produktivitas } \\
\text { primer } \\
\text { (g C/m²/tahun) } \\
\text { (g C/m } / \mathrm{m}^{2} / \text { year) }\end{array}$ & $\begin{array}{c}\text { Potensi ikan } \\
\text { (g C-udang/tahun) } \\
\text { Fish potential } \\
\text { (g C-shrimp/year) }\end{array}$ & $\begin{array}{l}\text { Produktivitas } \\
\text { primer } \\
\text { (g C/m²/tahun) } \\
\text { (g C/m } / \mathrm{m}^{2} / \text { year) }\end{array}$ & $\begin{array}{c}\text { Potensi ikan } \\
\text { (g C-udang/tahun) } \\
\text { Fish potential } \\
\text { (g C-shrimp/year) }\end{array}$ \\
\hline 1 & 5.60 & $12,715,646.20$ & 5.40 & $10,227,473.80$ \\
\hline 2 & 5.57 & $12,487,396.80$ & 5.15 & $11,946,556.70$ \\
\hline 3 & 5.57 & $13,713,922.80$ & 5.49 & $11,645,283.10$ \\
\hline 4 & 5.76 & $14,183,801.70$ & 5.43 & $11,322,663.10$ \\
\hline 5 & 5.81 & $13,060,354.80$ & 5.36 & $10,095,558.40$ \\
\hline 6 & 5.64 & $13,705,918.10$ & 5.10 & $10,021,149.70$ \\
\hline 7 & 5.74 & $12,721,344.80$ & 5.06 & $11,008,954.90$ \\
\hline 8 & 5.60 & $13,171,788.20$ & 5.31 & $10,959,665.20$ \\
\hline Rataan (Average) & 5.66 & $13,220,021.70$ & 5.29 & $10,903,413 \cdot 10$ \\
\hline Standar deviasi & 0.10 & $594,803.46$ & 0.16 & $728,648.98$ \\
\hline \multirow{2}{*}{$\begin{array}{l}\text { Sekali panen (dalam setahun } \\
\text { diestimasikan tiga kali panen) }\end{array}$} & \multicolumn{2}{|c|}{$\begin{array}{c}\text { 4,406,673.89 (g C-udang/panen)/ } \\
\text { (g C-shrimp/harvest) }\end{array}$} & \multicolumn{2}{|c|}{$\begin{array}{c}\text { 3,634,471 (g C-udang/panen)/ } \\
\text { (g C-shrimp/harvest) }\end{array}$} \\
\hline & \multicolumn{2}{|c|}{$\begin{array}{c}4.40 \text { (ton C-udang/panen)/ } \\
\text { (g C-shrimp/harvest) }\end{array}$} & \multicolumn{2}{|c|}{$\begin{array}{l}\text { 3.63(ton C-udang/panen)/ } \\
\text { (g C-shrimp/harvest) }\end{array}$} \\
\hline
\end{tabular}


Tabel 4. Hasil pengukuran kualitas air

Table 4. Water quality measurement results

\begin{tabular}{|c|c|c|c|c|c|}
\hline \multirow{2}{*}{$\begin{array}{l}\text { Parameter } \\
\text { Parameters }\end{array}$} & \multirow{2}{*}{$\begin{array}{c}\text { Satuan } \\
\text { Unit }\end{array}$} & \multicolumn{2}{|c|}{ Tam bak (Ponds) } & \multirow{2}{*}{ Optimum } & \multirow{2}{*}{$\begin{array}{l}\text { Referensi } \\
\text { Reference }\end{array}$} \\
\hline & & 1 & 2 & & \\
\hline Suhu (Temperature) & ${ }^{\circ} \mathrm{C}$ & $27.3-28.5$ & $27.5-29$ & $28-30$ & Permen-KP No. 75 Tahun 2016 \\
\hline Kecerahan (Brightness) & $\mathrm{cm}$ & $26.5-50.4$ & $29.3-50.3$ & $>25$ & Kordi \& Tancung (2007) \\
\hline Salinitas (Salinity ) & ppt & $26-28$ & $28-30$ & $20-28$ & Amri \& Kana (2008) \\
\hline $\mathrm{pH}$ & $\mathrm{pH}$ & $7.4-8.3$ & $8.2-8.8$ & $7.5-8.5$ & Permen-KP No. 75 Tahun 2016 \\
\hline DO & $\mathrm{mg} / \mathrm{L}$ & $7.36-7.88$ & $7.18-7.40$ & $4-7$ & Amri \& Kana (2008) \\
\hline $\mathrm{CO}_{2}$ & $\mathrm{mg} / \mathrm{L}$ & $17.98-23.47$ & $10.32-16.48$ & $<60$ & Effendi (2003) \\
\hline Nitrat (Nitrate) & $\mathrm{mg} / \mathrm{L}$ & $0.05-0.14$ & $0.08-0.10$ & $0.4-0.8$ & Clifford (1998) \\
\hline Ortofosfat (Orthophosphate) & $\mathrm{mg} / \mathrm{L}$ & $0.06-0.14$ & $0.04-1.12$ & $>0.02$ & Sellers \& Markland (1987) \\
\hline TOM & $\mathrm{mg} / \mathrm{L}$ & $43.33-53.88$ & $35-43.33$ & $55-90$ & Permen-KP No. 75 Tahun 2016 \\
\hline Klorofil (Chlorophyll) & $\mathrm{mg} / \mathrm{m}^{3}$ & 19.1-27.1 & $16.78-22.75$ & $<5$ & Dede et al . (2014) \\
\hline
\end{tabular}

tingkat laju fotosistesis yang dilakukan oleh fitoplankton.

Kisaran nilai salinitas adalah 26-28 ppt. Kadar salinitas dalam perairan berkaitan dengan proses moulting yang dilakukan oleh udang. Semakin tinggi salinitas akan berakibat pada kegagalan proses moulting, namun semakin rendah salinitas akan mempercepat proses moulting pada udang (Buwono, 1993). Udang vaname membutuhkan salinitas yang berbeda sesuai dengan fase perkembangan dalam siklus hidupnya. Induk dan udang dewasa yang akan bertelur memerlukan salinitas lebih tinggi, yaitu 28 ppt, sampai dengan fase larva. Setelah memasuki fase postlarva sudah mulai membutuhkan salinitas di bawah 28 ppt (Amri \& Kanna, 2008; Edhy et al., 2010).

Batas toleransi ikan dan udang terhadap konsentrasi $\mathrm{pH}$ antara 7,5-8,7 dan optimum bagi pemeliharaan udang 8,0-8,5 (Amri \& Kanna, 2008) sesuai dengan kondisi tambak. Konsentrasi $\mathrm{pH}$ air dipengaruhi oleh konsentrasi karbondioksida $\left(\mathrm{CO}_{2}\right)$ dalam perairan. Semakin banyak konsentrasi $\mathrm{CO}_{2}$ dalam perairan, maka menurunkan konsentrasi ion hidrogen dalam air; artinya, perairan menjadi asam akibat terbentuknya asam karbonat (Effendi, 2003; Edhy et al., 2010). Kisaran konsentrasi $\mathrm{CO}_{2}$ selama penelitian masih di bawah ambang batas atas toleransi bagi udang, namun harus disertai dengan oksigen terlarut yang cukup. Dalam perairan karbondioksida tidak boleh melebihi 60 mg/L (Effendi, 2003). Sejalan dengan kegiatan usaha budidaya yang sedang berjalan, bahan organik pada tambak akan mengalami peningkatan yang diakibatkan oleh sisa pakan, hasil ekskresi biota air yang ada dan hasil dari perombakan bahan organik.

Kadar oksigen pada perairan tambak masih tergolong baik untuk pertumbuhan udang. Kandungan oksigen terlarut yang baik bagi kehidupan ikan dan udang adalah sebesar $>3 \mathrm{mg} / \mathrm{L}$ dengan kondisi optimum pertumbuhan udang membutuhkan kadar oksigen terlarut 4-7 mg/L (Amri \& Kanna, 2008). Oksigen terlarut dimanfaatkan oleh organisme untuk melakukan proses respirasi dan proses dekomposisi yang dilakukan oleh mikroorganisme. Kandungan bahan organik, baik pada perairan alami maupun petakan tambak apabila dalam jumlah tinggi merupakan salah satu hambatan bagi kehidupan organisme yang dipelihara. Total bahan organik pada tambak tidak terlalu tinggi yaitu $<70$ mg/L. Kisaran total bahan organik untuk kondisi optimal budidaya udang adalah 55-90 mg/L (Permen-KP Nomor 75, 2016).

Tingkat kesuburan perairan juga dapat ditentukan dari unsur hara yang tersedia untuk pakan alami, yaitu nitrat dan fosfat. Kedua unsur hara tersebut menjadi faktor pembatas bagi pertumbuhan fitoplankton (Welch \& Lindell, 1980) dan juga dapat mengakibatkan terjadinya blooming algae apabila kedua unsur tersebut tinggi konsentrasinya (Sellers \& Markland, 1987). Nilai nitrat dalam masa penelitian berkisar 0,08-0,10 mg/L; masih tergolong rendah untuk perairan tambak. Nilai nitrat yang rendah ini tidak baik bagi pertumbuhan udang, karena konsentrasi nitrat yang optimum bagi kehidupan udang adalah berkisar 0,4-0,8 mg/mL; namun dapat diatasi dengan pemberian pakan tambahan (Dede et al., 2014). Perubahan nilai ortofosfat dapat memengaruhi struktur komunitas fitoplankton dan tingkat kesuburan perairan. Kisaran fosfat yang didapatkan tergolong pada perairan dengan tingkat kesuburan eutrofik. Kisaran ortofosfat yang didapatkan adalah 0,04-1,12 mg/L. Menurut Goldman \& Horne (1984), suatu perairan relatif subur apabila kandungan fosfatnya berkisar $0,06-1,0 \mathrm{mg} / \mathrm{L}$. 


\section{KESIMPULAN}

Berdasarkan hasil data lapangan dapat ditarik kesimpulan bahwa status trofik pada tambak di UPT Air Payau dan Laut, Probolinggo tergolong perairan eutrofik sedang. Potensi produksi udang dalam setahun adalah 13,22 ton C-udang/tahun pada petak tambak-1 dan 10,90 ton C-udang/tahun untuk petak tambak-2.

\section{UCAPAN TERIMA KASIH}

Penelitian ini mendapatkan dana PNBP tahun 2018 dari Fakultas Perikanan dan IImu Kelautan, Universitas Brawijaya, serta untuk Kepala UPT Air Payau dan Laut, Probolinggo yang telah mengijinkan kami untuk melakukan penelitian di UPT Air Payau dan Laut.

\section{DAFTAR ACUAN}

Adiwidjaya, D., Supito, \& Iwan S. (2008). Penerapan teknologi budidaya udang vaname: vannamei semiintensif pada lokasi tambak salinitas tinggi. J. Media Budidaya Air Payau Perekayasaan, 7, 54-72.

Amri, K. \& Kanna, I. (2008). Budi daya udang vaname secara intensif, semi intensif dan tradisional. Jakarta: PT Gramedia Pustaka Utama, $170 \mathrm{hlm}$.

Beveridge, M.C.M.(1984). Cage and pen fish farming:carrying capacity models and environmental impact. FAO Fish. Tech. Pap., 255, 131 pp.

Buwono, I.D. (1993). Tambak udang windu sistem pengelolaan berpola intensif. Yogyakarta: PT Kanisius, hlm. 29-37.

Carlson, R.E. (1977). A trophic state index for lakes. Limnology and Oceanography, 22(2), 361-369.

Clifford, H.C. (1998). Management of ponds stocked with blue shrimp Litopenaeus stylirostris. Proceeding of thelst Latin American Congress on the Shrimp Culture. Panama City, Panama, p. 101-109.

Dede, H., Aryawati, R., \& Diansyah, G. (2014). Evaluasi tingkat kesesuaian kualitas air tambak udang berdasarkan produktivitas primer PT Tirta Bumi
Nirbaya Teluk Hurun, Lampung Selatan (Studi Kasus). Maspari Journal, 6(1), 32-38.

Edhy, W.A., Kamaludin, A., Januar, P., \& Chaerudin, M.K. (2010). Budidaya udang putih (Litopenaeus vannamei Boone, 1931). Jakarta: CV Mulia Indah, $194 \mathrm{hlm}$.

Effendi, H. (2003). Telaah kualitas air bagi pengelolaan sumber daya dan lingkungan perairan. Cetakan kelima. Yogyakarta: Kanisius, $259 \mathrm{hlm}$.

Goldman, C.R. \& Horne, A.J. (1983). Limnology. New York: Mc. Graw Hill Book Company. 464 pp.

Kordi, K., dan Tancung, A.B. (2007). Pengelolaan kualitas air dalam budidaya perairan. PT. Rhineka Cipta. Jakarta., $208 \mathrm{hlm}$.

Nirmala, K., Yuniar., E., \& Budiardi, T. (2005). Produktivitas dan parameter kimia dasar tambak budidaya udang windu Penaeus monodon Fab. berumur 1 dan 3 tahun. Jurnal Akuakultur Indonesia, 4(1), 5-11.

Permanasari, S., Kusriani, M., \& Widjarnako, P. (2017). Tingkat kesuburan perairan di Waduk Wonorejo dalam kaitannya dengan potensi ikan. JFM R-Journal of Fisheries and Marine Research, 1(2), 88-94. DOl: $\quad$ http://dx.doi.org/10.21776/ ub.jfmr.2017.001.02.6.

Purwohadiyanto, Prapti. S., \& Andayani, S.. (2006). Pemupukan dan kesuburan perairan budidaya. Fakultas Perikanan, Jurusan Budidaya, Universitas Brawijaya, Malang, $124 \mathrm{hlm}$.

Raswin, M. (2003). Pembesaran ikan bandeng, modul pengelolaan air tambak. Direktorat Jendral Pendidikan Dasar dan Menengah, Departemen Pendidikan Nasional, $41 \mathrm{hlm}$.

Ryding, S.O. \& Rast, W. (1989). The control of eutrhophication of lakes and reservoir. New Jersey: The Porthenon Publishing Group, $314 \mathrm{hlm}$.

Sellers, B.H. \& Markland, H.R. (1987). Decaying lakes. Chichester, New York: John Wiley \& Sons, 254 pp.

Welch, E.B. \& Lindell, T. (1980). Ecological effects of waste water. Cambridge, London: Cambridge University Press, $337 \mathrm{pp}$. 